PART II. PHYSICAL ACTIVITY OF SOCIAL AND PROFESSIONAL GROUPS DZIAŁ II. AKTYWNOŚĆ FIZYCZNA GRUP SPOŁECZNYCH I ZAWODOWYCH

\title{
ROLE OF PHYSICAL ACTIVITY IN THE LIFESTYLE OF FRENCH NURSES
}

\section{AKTYWNOŚĆ FIZYCZNA W STYLU ŻYCIA PIELĘGNIAREK WE FRANCJI}

\author{
Amanda Dubray ${ }^{1(\mathrm{~A}, \mathrm{~B})}$, Józef Bergier $^{2(\mathrm{~A}, \mathrm{C}, \mathrm{D}, \mathrm{E}, \mathrm{F}, \mathrm{G})}$, Iwona Gładysz ${ }^{2(\mathrm{~A}, \mathrm{~B})}$ \\ ${ }^{1}$ Centre de Formations Paramédicales, Niort, France \\ ${ }^{2}$ Pope John Paul II State School of Higher Education in Biala Podlaska, Poland
}

Authors' contribution Wkład autorów: A. Study design/planning zaplanowanie badań B. Data collection/entry zebranie danych C. Data analysis/statistics dane - analiza i statystyki D. Data interpretation interpretacja danych E. Preparation of manuscript przygotowanie artykułu F. Literature analysis/search wyszukiwanie i analiza literatury G. Funds collection zebranie funduszy
Tables: 1

Figures: 7

References: 21

Submitted: 2017 Nov 06

Accepted: 2017 Nov 30

\section{Summary}

Background. Physical activity is a crucial component of a healthy lifestyle. Thus, it should be diagnosed in students as future elites, especially those in medical faculties, i.e. medical and nursing departments. The aim of the present research is knowledge about the level of physical activity of nurses, including the factors that determine it.

Material and methods. The research was carried out in 2017 and involved 279 nurses aged 21-30 (mean $23.5 \pm 2.4$ years) from the Medical Education Centre in Niort, France. The physical activity was assessed using the International Physical Activity Questionnaire (IPAQ) - long version, supplemented with additional questions.

Results. Most nurses (75.4\%) demonstrated a high level of physical activity or a moderate one $-18.9 \%$. Only in some persons ( $5.7 \%$ ), it could be described as low. The total level of physical activity was 6573.0 MET / min-week, and the dominant activity related to work or studying, i.e. 2823.2 MET, which amounted to $43.0 \%$ of the total activity. The place of origin - the city, as well as the year of study, the second and third year, turned out to be decisive factors significantly affecting the higher level of physical activity in nurses.

Conclusions. Nurses exhibit a high PA (physical activity) level and a correct BMI index, which proves that their lifestyle can be considered as healthy.

Keywords: nurses, physical activity, IPAQ, France

\section{Streszczenie}

Wprowadzenie. Aktywność fizyczna postrzegana jest jako bardzo ważna składowa zdrowego stylu życia. Należy ją diagnozować wśród studentów jako przyszłych elit, w tym szczególnie na kierunkach medycznych tj. lekarskim i pielęgniarskim. Celem podjętych badań jest poznanie poziomu aktywności fizycznej pielęgniarek, w tym czynników ją warunkujących.

Materiał i metody. W badaniach przeprowadzonych w 2017 r. wzieło udział 279 pielegniarek z Ośrodka Kształcenia Medycznego w Niort we Francji w przedziale wieku 21-30 lat, przy średniej wieku 23,5 22,4 lat. Oceny aktywności fizycznej dokonano Międzynarodowym Kwestionariuszem Aktywności Fizycznej (IPAQ) w wersji długiej, uzupełnionego o dodatkowe pytania.

Wyniki. Większość pielęgniarek $(75,4 \%)$ cechuje wysoki poziom aktywności fizycznej, przy 18,9\% poziomu umiarkowanego i tylko 5,7\% niskiego. Całkowity poziom aktywności fizycznej wyniósł 6573,0 MET/min-tydz., a dominującym obszarem była aktywność w pracy/ nauce - 2823,2 MET, która stanowi 43,0\%. Wśród czynników istotnie warunkujących wyższy poziom aktywności fizycznej pielęgniarek, wykazano z miejscem pochodzenia - miasto, rokiem studiów - drugi i trzeci i prawidłowym wskaźnikiem BMI.

Wnioski. Pielęgniarki cechuje wysoki poziom aktywności fizycznej i prawidłowy wskaźnik BMI, co wystawia pozyty wną ocenę ich stylu życia i dobrze świadczy o procesie dydaktycznym w trakcie studiów.

Słowa kluczowe: pielęgniarki, aktywność fizyczna, IPAQ, Francja 


\section{Introduction}

It is widely accepted that physical activity plays a crucial role in a healthy lifestyle. That is why, it is worth looking at its levels in different social and professional groups, preferably using the same assessment method, which allows for comparing the achieved PA results. The International Physical Activity Questionnaire [1] has already been recognized in the literature concerning PA because, with its help, much research has been carried out in students coming from various countries, for example, Croatia [2], Ukraine [3], Germany [4], Portugal [5], Estonia [6], the Visegrad countries [7], and Poland [8,9,10,11].

Conducting studies in medical science students is of particular importance as they may be seen as future promoters of a healthy lifestyle $[12,13,14,15,16,17,18]$.

Thus, the research on the physical activity in nurses should also find its place in the literature referring to the IPAQ questionnaire application and results $[19,20,21]$. A closer look at physical activity in nurses from different countries might expand the knowledge about this challenging profession.

\section{Material and methods}

The following paper aims to acquire knowledge on the physical activity in nurses from the Medical Education Centre in Niort, France, and the factors that determine it.

Altogether, 298 nurses were examined in June and November 2017, but 279 answer sheets were used in the analysis, due to the lack of competence in the remaining individuals ( 9 persons). The nurses' age was 21-30 years, the mean being $23.5 \pm 2.4$ years. The students represented all three years of study: year I (37.5\%), year II (33.0\%), and year III (18.6\%). Most of them came from rural backgrounds $-55.6 \%$, and $44.4 \%$ from urban areas. Further, the majority would stay in student dormitories or rented accommodation, whereas the remaining ones in family homes, i.e. $62.5 \%$, and $37.5 \%$ respectively. $81.7 \%$ would participate in organised sports activities and, accordingly, demonstrate higher or moderate physical fitness ( $75.3 \%$ and $23.3 \%$ respectively). Only 4 persons (1.4\% of the tested group) would exhibit a low level. As for the amount of leisure time, the majority would see it as sufficient (53.1\%), 44.4\% - as insufficient, and 2.5\% complained of its lack (table 1).

Table 1. Characteristics of the students

\begin{tabular}{|c|c|c|}
\hline \multicolumn{3}{|c|}{ Place of residence } \\
\hline \multicolumn{2}{|l|}{ City } & Countrywide \\
\hline \multicolumn{2}{|l|}{$44.4 \%$} & $55.6 \%$ \\
\hline \multicolumn{3}{|c|}{ Place of residence while studying } \\
\hline Family Home & \multicolumn{2}{|c|}{ Dormitory/hostel/rented accommodation } \\
\hline $37.5 \%$ & \multicolumn{2}{|c|}{$62.5 \%$} \\
\hline \multicolumn{3}{|c|}{ Year of study } \\
\hline First & Second & Third \\
\hline $48.4 \%$ & $33.0 \%$ & $18.6 \%$ \\
\hline \multicolumn{3}{|c|}{ Amount of leisure time } \\
\hline Sufficient amount & Insufficient amount & Lack \\
\hline $53.1 \%$ & $44.4 \%$ & $2.5 \%$ \\
\hline \multicolumn{3}{|c|}{ Self-assessment of physical fitness } \\
\hline High & Moderate & Low \\
\hline $75.3 \%$ & $23.3 \%$ & $1.4 \%$ \\
\hline \multicolumn{3}{|c|}{ BMI } \\
\hline Correct weight & \multicolumn{2}{|r|}{ Overweight } \\
\hline $70.5 \%$ & \multicolumn{2}{|r|}{$29.5 \%$} \\
\hline \multicolumn{3}{|c|}{ Participation in organised sports activities } \\
\hline \multicolumn{2}{|l|}{ Yes } & No \\
\hline $18.3 \%$ & \multicolumn{2}{|r|}{$81.7 \%$} \\
\hline
\end{tabular}

A diagnostic survey using a questionnaire technique - the International Physical Activity Questionnaire (IPAQ-L) was applied as a test method and the study itself was conducted by trained academic teachers. The research sheet was supplemented with additional questions regarding age, place of origin, year of study, amount of free time, self-assessment of physical fitness, place of residence, height and weight, participation in organised sports activities as well as the performed work. 


\section{Results}

\section{Level of physical activity and its domains}

The total level of physical activity was 6573.0 MET / min-week. The dominant area of activity in nurses is activity related to studying/work - 2823.2 MET, which amounted to 43.0\%. Transportation physical activity, housework and in sports would share similar values, i.e. 17.0\%, 19.8\%, 20.3\% respectively (Figure 1).

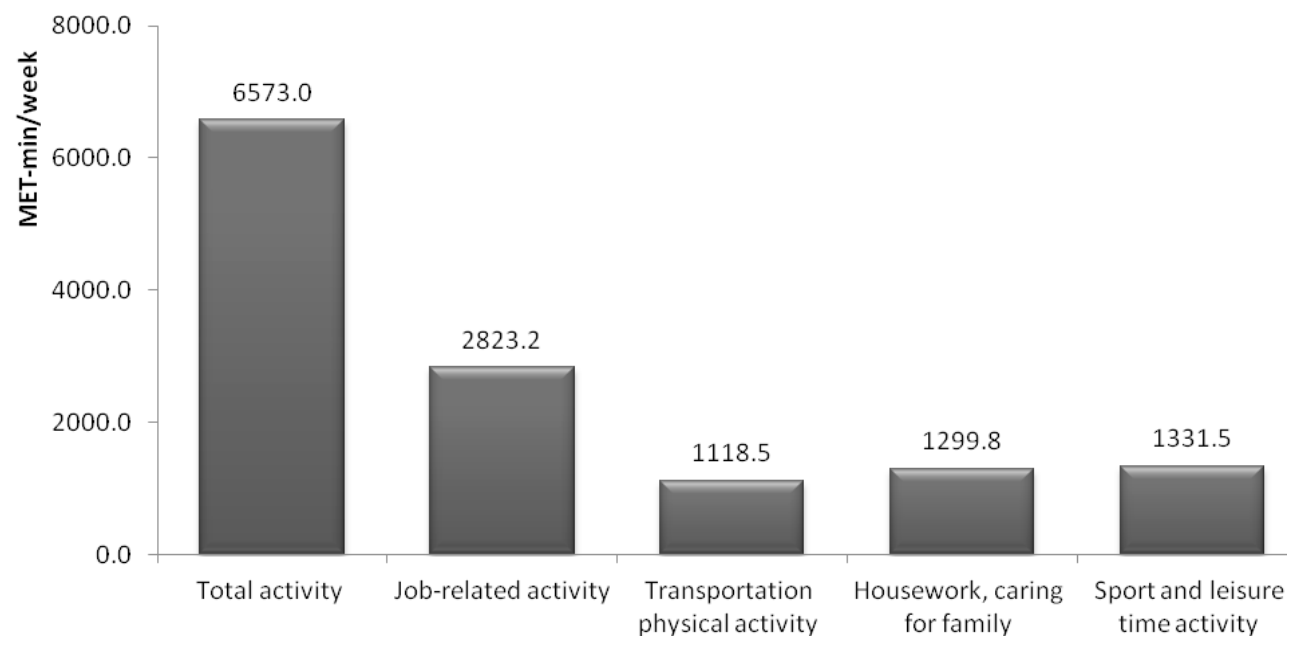

Figure 1. Total physical activity and its domains

Clearly, the majority of respondents demonstrated high (75.4\%), or moderate (18.9\%) activity. Only 5.7\% would be classified as those with low PA level (Figure 2).

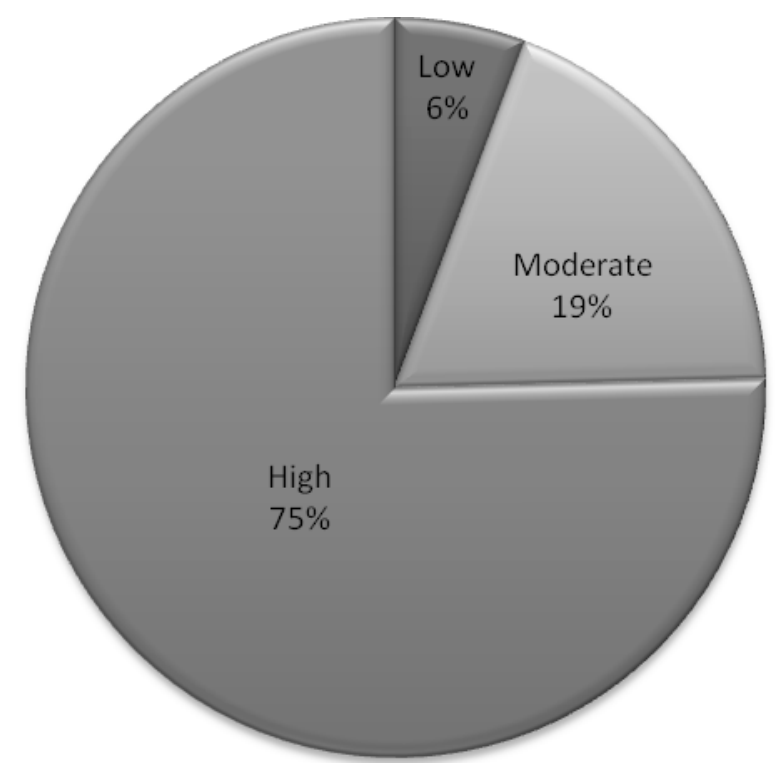

Figure 2. Levels of physical activity

Factors determining the level of physical activity.

While looking for significant relationships between variables and physical activity, the following factors were taken into account: place of residence, year of study, place of origin, amount of leisure time, self-assessment of physical fitness, BMI and participation in sports activities. As for the factors determining a higher level of total physical activity, a significant relationship was found between the place of origin, i.e. the city, the year of study (the second or third year) and the correct BMI value (Figure 3). 


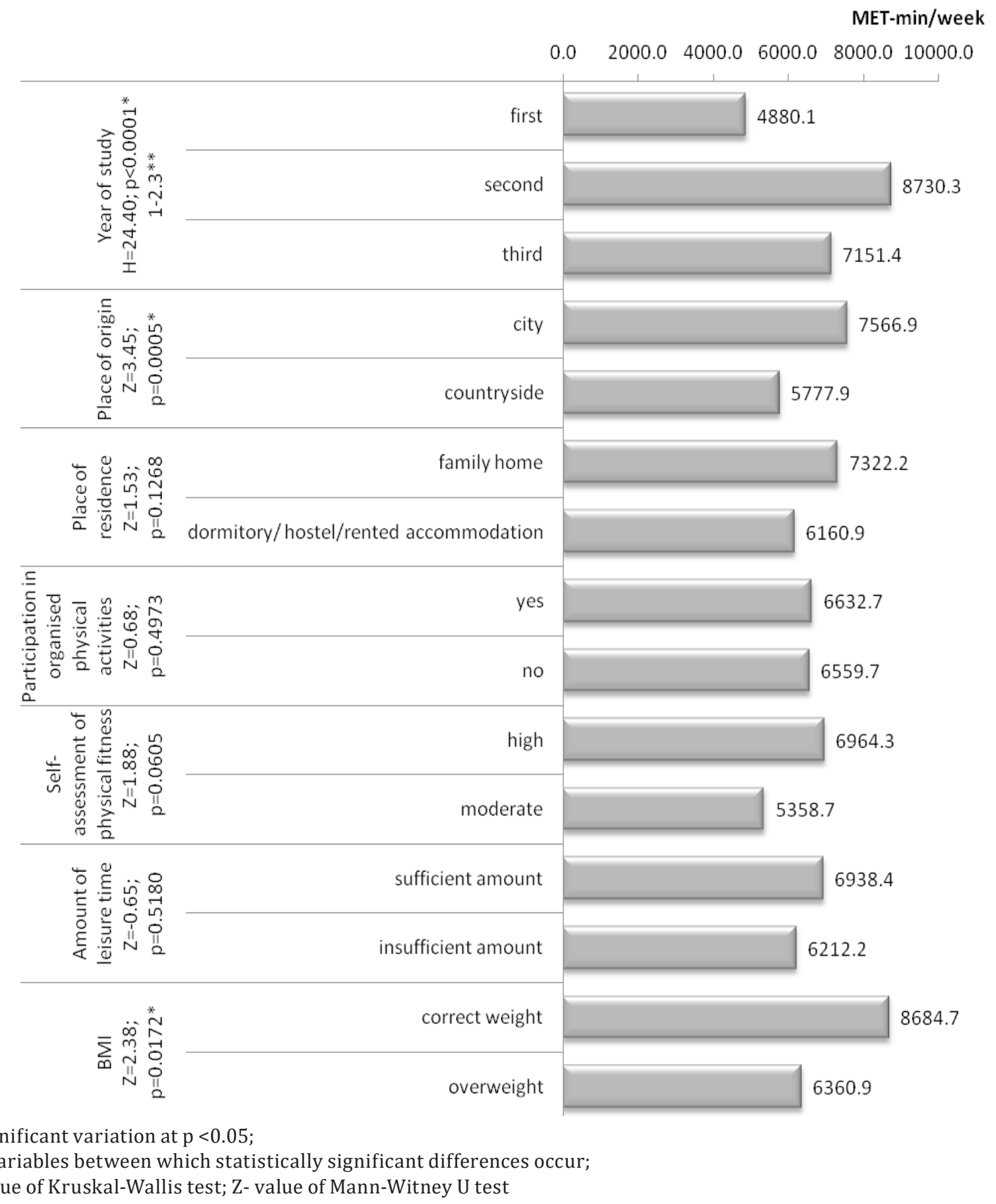

Figure 3. Total physical activity and selected determinants

Once the variables significantly affecting the total level of physical activity were identified, a more detailed analysis was conducted with regard to the PA domains (Figure 4-6). 


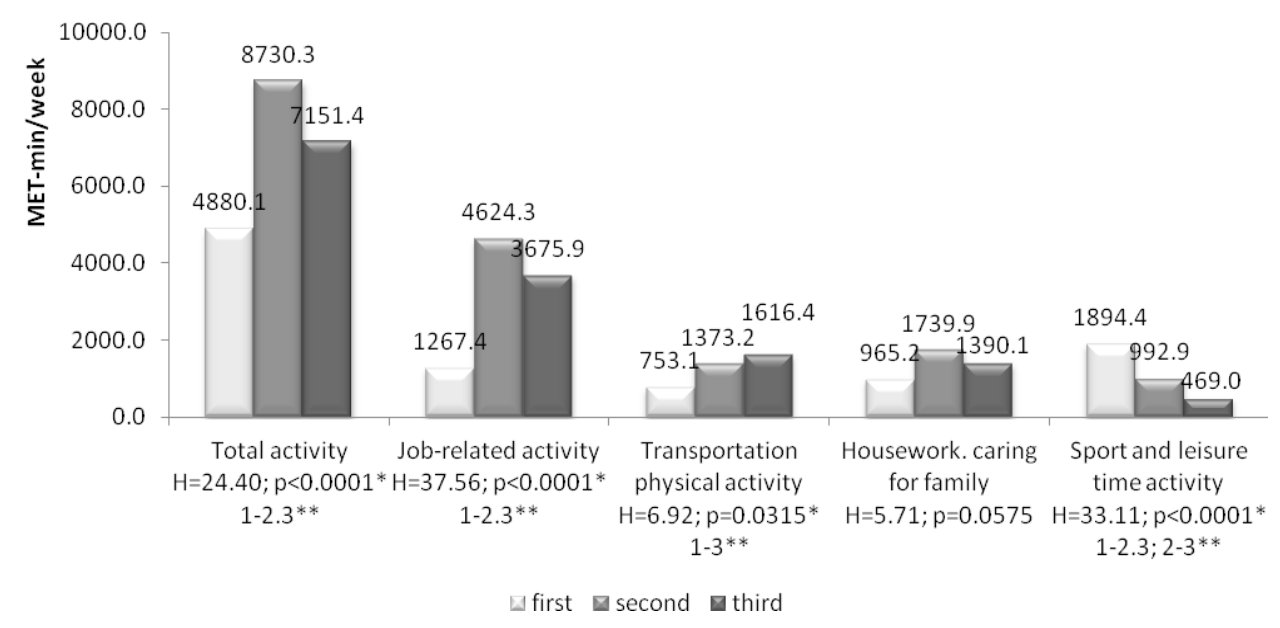

* -a significant variation at $\mathrm{p}<0.05$;

** - variables between which statistically significant differences occur;

$\mathrm{H}$ - value of Kruskal-Wallis test

Figure 4. Total physical activity and its domains with regard to the year of study

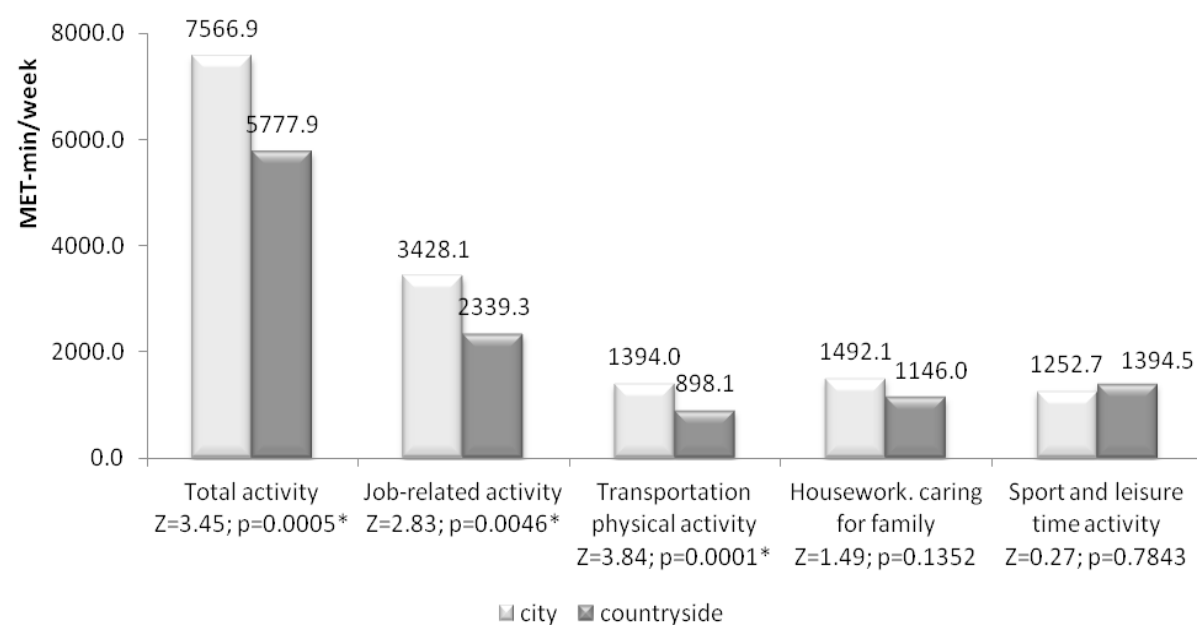

* -a significant variation at $\mathrm{p}<0.05$;

Z-value of the Mann-Whitney U test

Figure 5. Total physical activity and its domains with regard to the place of origin

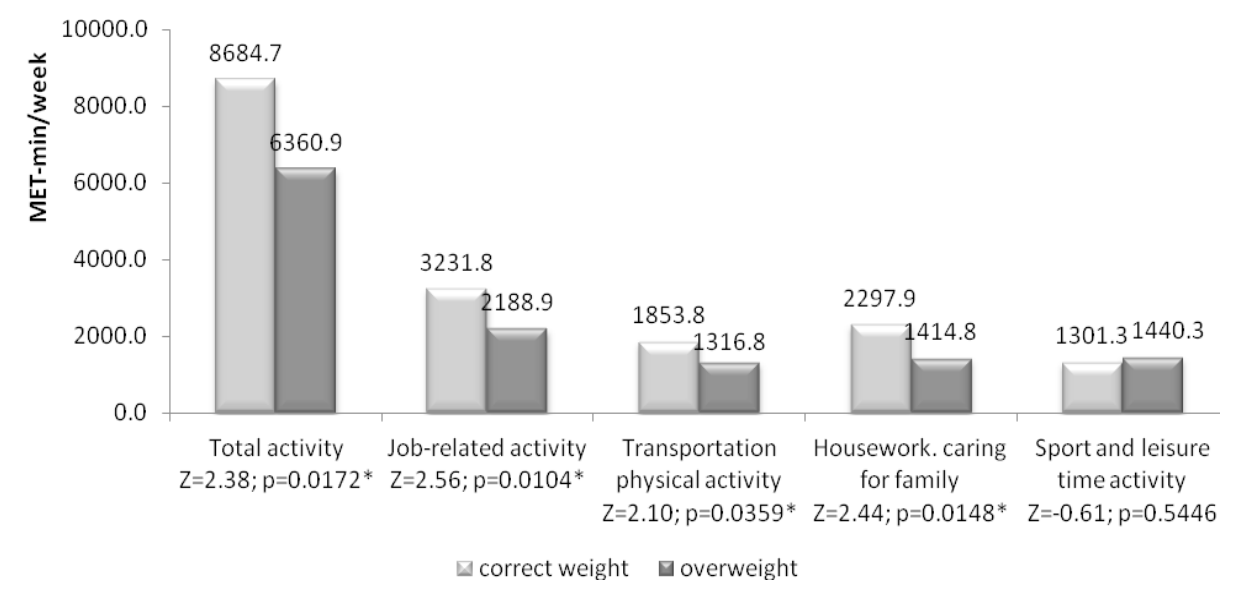

* - significant variation at $\mathrm{p}<0.05$;

$\mathrm{Z}$ - value of the Mann-Whitney U test

Figure 6. Total physical activity and its domains with regard to BMI 
Physical activity and its domains with regard to the year of study.

The first-year students demonstrated the lowest activity (4880.1 MET) when compared to those in the second and third year (8730.3 MET and 7111.4 MET respectively). Such important unfavourable differences in the younger females were also demonstrated in their activity related to work and transportation. On the other hand, in the area of sports activity, younger students were significantly more active (Figure 4).

Physical activity and its domains with regard to the place of origin.

Significantly higher values in total physical activity in the examined respondents were demonstrated in the students coming from cities (7566.9 MET), when compared to those from the countryside (5777.9 MET), with $\mathrm{p}=0.0005$, as well as in the job-related and transportation domains, with better results also visible in the respondents coming from urban areas (Figure 5).

Physical activity and its domains with regard to the BMI index.

Significantly higher total physical activity was exhibited in the students with the correct BMI (8684.7 MET), when compared to the overweight persons (6560.9 MET), i.e. $\mathrm{p}=0.0172$, as well as in job-related, transportation and housework physical activities. No such differences were visible in the domain of sports (Figure 6).

The analysed variables were also related to the three levels of physical activity: high, moderate, and low. As a result of the computation, a significant dependence was found again between the place of origin and the BMI index, with better results demonstrated by those coming from the city and having correct BMI (Figure 7).

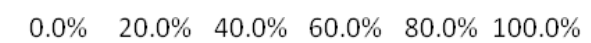

\begin{tabular}{|c|c|c|c|}
\hline$>\stackrel{9}{\vec{A}}$ & first & $9.6 \% \quad 31.1 \%$ & $59.3 \%$ \\
\hline 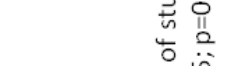 & second & $8.7 \% 18.5 \%$ & $72.8 \%$ \\
\hline 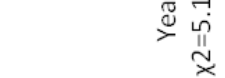 & third & $7.7 \% \quad 25.0 \%$ & $67.3 \%$ \\
\hline 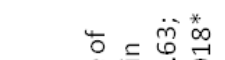 & city & $4.0 \% 20.2 \%$ & $75.8 \%$ \\
\hline 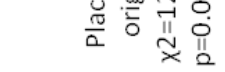 & countryside & $12.9 \% \quad 30.3 \%$ & $56.8 \%$ \\
\hline ๘号讨令 & family home & $8.7 \% \quad 23.3 \%$ & $68.0 \%$ \\
\hline 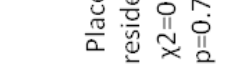 & dormitory/hostel/rented accommodation & $9.3 \% \quad 27.3 \%$ & $63.4 \%$ \\
\hline 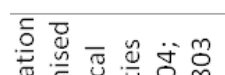 & yes & $3.9 \% 7.7 \%$ & $78.4 \%$ \\
\hline 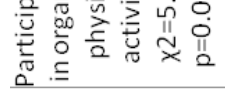 & no & $10.1 \% \quad 27.6 \%$ & $62.3 \%$ \\
\hline 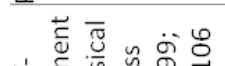 & high & $8.6 \% 24.8 \%$ & $66.7 \%$ \\
\hline 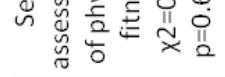 & moderate & $10.8 \% \quad 29.2 \%$ & $60.0 \%$ \\
\hline 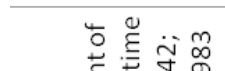 & sufficient amount & $10.9 \% \quad 24.5 \%$ & $64.6 \%$ \\
\hline 定章亚 & insufficient amount & $5.7 \% \quad 27.6 \%$ & $66.7 \%$ \\
\hline$-\underset{\sim}{-} \stackrel{-}{+}_{\infty}^{*}$ & correct weight 2 & $2.3 \% 7.4 \%$ & $80.2 \%$ \\
\hline 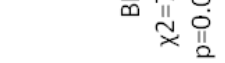 & overweight & $13.9 \% \quad 22.2 \%$ & $63.9 \%$ \\
\hline . & Total & $5.7 \% 18.9 \%$ & $75.4 \%$ \\
\hline
\end{tabular}

* - significant variation at $\mathrm{p}<0.05$;

$\mathrm{X}^{2}$ - value of Pearson's Chi- square test

Figure 7. Activity level in the examined students and selected features 


\section{Discussion}

The advantage of evaluating physical activity using IPAQ is the ability to compare the achieved results in the persons representing particular social and professional groups in different countries.

Similar studies in students are conducted in various countries $[2,3,4,5,6,7,8,9,10,11]$, including persons in medical faculties $[12,13,14,15,16]$. However, as far nurses are concerned, they have been examined far less frequently $[19,20,21]$.

It should be stated that, generally, the French nurses' evaluation concerning their physical activity was positive, which may result from their high awareness gained during the studies and knowledge about the role of physical activity in a healthy lifestyle. Similarly, a high physical activity was demonstrated in Polish nurses, who were also assessed with the IPAQ questionnaire [19.2].

The above hypothesis may be confirmed by the fact that the majority of the analysed factors such as the available leisure time, self-assessment of physical fitness, participation in organised sports activities, do not significantly affect greater physical activity.

What was positive about the examined nurses was their participation in a variety of organised sports activities, a correct BMI index and high self-assessment of physical fitness, which can only prove the beneficial evaluation of their active lifestyle. What was somewhat surprising was the lack of a significant relationship between high self-assessment of physical fitness and the level of physical activity, which is shown in other works as well. A higher PA level in students in later years of study seems a favourable phenomenon, which is unusual for other courses $[7,8]$.

The fact that nurses exhibit a proper lifestyle is confirmed by the numbers, as $75.0 \%$ of them meet the recommendations concerning a high level of physical activity, and only a few persons demonstrate a low level. The two-fold analysis of the factors determining a higher level of activity confirmed the relationship between the place of origin (city, village) and the BMI index. It might result from the respondents' greater awareness of how significant physical activity is. Higher physical activity in people with the correct BMI index, when compared to their overweight friends, may indicate that the previously expressed opinion, i.e. that it is greater awareness, including caring for one's figure, that contributes to greater physical activity, is true.

It should be noted, however, that the high PA level visible in nurses in Poland $[19,20]$ may be associated with an unfavourable health condition manifesting itself by ailments in the lower part of the spine.

\section{Conclusions}

The favourable data on the lifestyle of the examined French nurses should be welcome, especially those concerning their high PA level as well as the correct BMI. Such a positive evaluation of their lifestyle with regard to the role of physical activity is a good sign for the educational process in college and, at the same time, might become a good prognosis factor for the decisive role that nurses may play in promoting physical activity in their professional life.

\section{References:}

1. Booth ML. Assessment of Physical Activity: An International Perspective. Res Quart Exerc Sport. 2000; 71:114-20.

2. Pedišić Ž, Rakovac M, Bennie J, Jurakić D, Bauman AE. Levels and correlates of domain-specific physical activity in university students: Cross-sectional findings from Croatia. Kinesiology 2014; 46: 1: 12-22.

3. Pavlova I, Vynogradskyi B, Kurchaba T, Zikrach D. Influence of leisure-time physical activity on quality of life of Ukrainian students. Journal of Physical Education and Sport (JPES). 2017; 17(3): 1037-1042.

4. Dichl K, Hilger J. Physical activity and the transition from school to University: a cross-sectional survey among University students in Germany. Sci Sports 2016; Vol. 31(4):223-226.

5. Clemente FM, Nikolaidis PT, Martins FML, Mendes RS. Physical activity patterns in university students: Do they follow the public health guidelines? PLOS ONE 2016; 11(3): e0152516. DOI: 10.1371/journal. pone.0152516.

6. Lusmägi P, Einasto M, Eve-Liis Roosmaa E-L. Leisure-time Physical Activity Among Different Social Groups of Estonia: Results of the National Physical Activity Survey, Physical Culture and Sport. Studies and Research 2016; LXIX: 43-52. DOI: 10.1515/pcssr-2016-0004.

7. Junger J, Niźnikowska E, Bergier B, Frömel K, Salonna F, Ács P, et al. A field of study as a factor determining physical activity, BMI indicator and self-assessment of physical activity of students in the Visegrad Countries. Health Problems of Civilization. 2016; 10(4): 14-25. 
8. Bergier J, Bergier B, Niźnikowska E, Junger J, Ács P, Frömel K, et al. The diversity of the place of residence of students and their level of physical activity. Central European Journal of Sport Sciences and Medicine. 2016; 13(1): 123-132.

9. Biernat E. Aktywność fizyczna mieszkańców Warszawy. Na przykładzie wybranych grup zawodowych. Warszawa: Szkoła Główna Handlowa; 2011 (in Polish).

10. Mynarski W, Rozpara M, Królikowska B, Puciato D, Graczykowska B. Jakościowe i ilościowe aspekty aktywności fizycznej. Opole: Oficyna Wydawnicza Politechnika Opolska; 2012.

11. Kapka-Skrzypczak L, Bergier B, Diatczyk J, Niedźwiecka J, Biliński P, Wojtyła A. Dietary habits and body image perception among Polish adolescents and young adults - a population based study. Ann Agric Environ Med. 2012; 19(2): 299-308.

12. Dąbrowska-Galas M, Plinta R, Dąbrowska J, Skrzypiec-Plinta V. Physical activity in students of the Medical University of Silesia in Poland. Physical Therapy. 2015; 93(3): 384-392.

13. Popovych D, Bergier J, Sopel O, Tsybulska L, Korda M. Physical activity levels in female students of Ternopil State Medical University. International Journal of Medicine and Medical Research. 2016; 2(2): 37-41.

14. Lobelo F, Duperly J, Frank E. Physical activity habits of doctors and medical students influence their counselling practices. Br J Sports Med. 2009; 43: 89-92.

15. Stanford FC, Durkin MW, Blair SN, Powell CK, Poston MB, Stallworth JR. Determining levels of physical activity in attending physicians, resident and fellow physicians and medical students in the USA. Br J Sports Med. 2012; 46: 360-364.

16. Frank E, Tong E, Lobelo F. Physical activity levels and counseling practices of U.S. medical students. Med Sci Sports Exercise. 2008; 40(3): 413-421.

17. Sigmundová D, Chmelík F, Sigmund E, Feltlová D, Frömel K. Physical activity in the lifestyle of Czech university students: Meeting health recommendations. European Journal of Sport Science. 2013; 13(6): 744-750.

18. Angyan L, Teczely T, Mezey B, Lelovics Z. Selected physical characteristics of medical students. Med. Educ. 2003;8:1-6.

19. Bergier J, Kubińska Z, Bergier B. Aktywność fizyczna pielęgniarek z uwzględnieniem wykształcenia. Turystyka i Rekreacja 2012; 8:145-151.

20. Bergier J, Kubińska Z, Bergier B. Czas wolny a aktywność fizyczna pielęgniarek. Antropomotoryka 2012; 58:103-108.

21. Mynarski W, Grabara M, Nawrocka A, Niestrój-Jaworska M, Wołkowycka B, Cholewa J. Rekreacyjna aktywność fizyczna i dolegliwości mięśniowo-szkieletowe pielęgniarek. Physical Recreational Activity and Munsculoskeletal Disorders in Nurses. Medycyna Pracy 2014; 65(2):181-188. 